УДК $615.21 / .27-056.3$

Сенсибилизация гепарином мю-рецепторов, иницированных фентанилом

\author{
Хомутов А.Е. ${ }^{1}$, Дерюгина А.В. ${ }^{1}$, Лизунова А.С. ${ }^{2}$, Боброва З.В. ${ }^{3}$ \\ ${ }^{1}$ ФАОУ ВО «Нижегородский государственный университет им. Н.И. Лобачевского» \\ ${ }^{2}$ ФББОУ ВО «Рязанский государственный медицинский университет им. академика И.П. Павлова» Минздрава \\ России \\ ${ }^{3}$ ФБУН Институт физиологически активных веществ РАН (г. Черноголовка)
}

\title{
Heparin sensitization of fentanyl initiated mu-receptors
}

\author{
${ }^{\dagger}$ Khomutov A.E. ${ }^{1}$, Deryugina A.V. ${ }^{1}$, Lizunova A.S. ${ }^{2}$, Bobrova Z.V. ${ }^{3}$ \\ ${ }^{1}$ Lobachevsky State University of Nizhny Novgorod \\ ${ }^{2}$ Ryazan State Medical University n.a. academician I.P. Pavlov \\ ${ }^{3}$ Institute of Physiologically Active Substances (Chernogolovka)
}

\section{АННОТАЦИЯ}

Гепарин является антикоагулянтом, широко применяемым в клинической практике. Помимо антикоагуляционной активности гепарин обладает цитостатическим, бактериостатическим, антилипемическим, радиопротективным действием, проявляет антиаллергический и гипотензивный эффекты. Гепарин модулирует кардиотропные, нейротропные, антигипоксические, антиишемические свойства регуляторных пептидов и фармакологических средств, применяющихся при обезболивании и наркозе. При этом крайне мало информации об антиноцицептивном действии гепарина.

Цель настоящей работы - изучение влияния гепарина при сочетанном применении с опиоидным агонистом фентанилом на мю-рецепторы на спинальном и супраспинальном уровнях. В опытах на лабораторных крысах установлено, что гепарин при предварительном и совместном введении с фентанилом увеличивает латентный период реакции отведения хвоста и реакции облизывания лап. Налоксон, являющийся антагонистом опиоидных рецепторов, снижает антиноцицептивную эффективность. Протамина сульфат также снижает уровень сенсибилизации гепарином опиоидных рецепторов.

Таким образом, полученные данные позволяют говорить о сенсибилизирующем действии гепарина на мюопиоидные рецепторы, инициированные агонистом, на спинальном и супраспинальном уровнях.

\section{Ключевъе слова: гепарин, фентанил, налоксон, протамина сульфат, антиноцицептивное действие.}

\begin{abstract}
Heparin is an anticoagulant widely used in clinical practice. In addition to anticoagulant activity, heparin has a cytostatic, bacteriostatic, antilipemic, radioprotective effect, and exhibits antiallergic and hypotensive action. Heparin modulates cardiotropic, neurotropic, antihypoxic, anti-ischemic properties of regulatory peptides and pharmacological agents used in pain relief and anesthesia. At the same time, there is very little information about the antinociceptive effect of heparin.

The aim of this work is to study the effect of heparin in combination with the opioid agonist fentanyl on mu-opioid receptors at the spinal and supraspinal levels. In experiments on laboratory rats, it was established that heparin, when preadministered and combined with fentanyl, increases the latency in the tail flick test and the paw licking test. Naloxone, an opioid receptor antagonist, reduces antinociceptive efficacy of the studied compounds. Protamine sulfate also reduces the level of heparin sensitization of opioid receptors.
\end{abstract}

Поступила 06.10.2020

Принята 15.11 .2020

Автор, ответственный за переписку

Лизунова Алла Сергеевна: ФГБОУ ВО «Рязанский государственный медицинский университет им. акад. И.П. Павлова» Минздрава России. 390026, г. Рязань, ул. Высоковольтная, 9.

E-mail: lizunova-alla@mail.ru
Received 06.10.2020

Accepted 15.11.2020

Corresponding author

Lizunova Alla Sergeyevna: Ryazan State Medical University named after academician I.P. Pavlov, 9, Vysokovoltnaya str., Ryazan, 390026, Russia. E-mail: lizunova-alla@mail.ru 
Thus, the obtained data allow us to speak about the sensitizing effect of heparin on initiated by an agonist mu-opioid receptors at the spinal and supraspinal levels.

Keywords: heparin, fentanyl, naloxone, protamine sulfate, antinociceptive action.

\section{$\mathbb{B} \mathbb{B E}$ ДНHЕ}

Гепарин, применяющийся в клинической практике как антикоагулянт первого выбора, обладает целым рядом свойств, выходящих за рамки антикоагулянтной системы [1]. Помимо антикоагуляционной активности гепарин обладает цитостатическим [2], бактериостатическим [3], антилипемическим [4], радиопротективным [5] действием, выявлены его антиаллергический [6] и гипотензивный [7] эффекты. Сравнительно недавно была показана способность гепарина связывать и инактивировать природные токсины, входящие в состав пчелиного яда и некоторых змеиных ядов [8], а также взаимодействовать с некоторыми фармакологическими веществами $[9,10]$.

Эффекты гепарина обусловлены различными механизмами. В частности, показано, что многие эффекты гепарина связаны с его способностью модулировать уровень ионов кальция $\left(\mathrm{Ca}^{2+}\right)$ [11]. Процесс повышения внутриклеточного уровня $\mathrm{Ca}^{2+}$ обусловлен тем, что вследствие активации фосфолипазы С происходит гидролиз фосфоинозитидов, в результате чего образуется инозитол1,4,5-трифосфат (ИЗФ), который мобилизует выход внутриклеточного $\mathrm{Ca}^{2+}[12,13]$. Многие эффекты $\mathrm{Ca}^{2+}$ опосредованы белком кальмодулином, уровень которого может повышать цАМФ, что приводит к еще большему выходу $\mathrm{Ca}^{2+}$ из внутриклеточных резервов [11]. Гепарин оказывает выраженное гиперполяризующее действие и может изменять зарядность мембран, таким образом модулируя действие кальциевых каналов и регулируя уровень свободных ионов кальция, являющихся одним из важнейших индукторов выделения внутриклеточного $\mathrm{Ca}^{2+}$ [14].

Кроме того, у гепарина выявлена возможность образовывать комплексы с различными соединениями. Гепарин способен образовывать комплексы с положительно заряженными ионами металлов, катионами, в том числе органическими: $\mathrm{K}^{+}, \mathrm{Na}^{+}, \mathrm{Ca}^{2+}, \mathrm{Ba}^{2+}, \mathrm{Cu}^{2+}, \mathrm{Cl}^{-}, \mathrm{SO}_{4}{ }^{2-}, \mathrm{PO}_{4}{ }^{3-}$, $\left.\mathrm{CH}_{3} \mathrm{COO}^{-}[15,16]\right)$. Доказана способность гепарина образовывать комплексы с широким спектром аминокислот, белков, пептидов, ферментов, катионных соединений, при этом могут меняться как его собственные свойства, так и свойства веществ, вступающих с ним во взаимодействие [17-21]. Гепарин может образовывать комплексы с физи-

\section{INTRODUCTION}

Heparin, which is used in clinical practice as the first-line anticoagulant, has a number of properties that go beyond the anti-coagulant system [1]. In addition to anticoagulant activity, heparin has cytostatic [2], bacteriostatic [3], antilipemic [4], radioprotective [5] effects; its antiallergic [6] and hypotensive [7] action has been identified. Comparatively recently, the ability of heparin to bind and inactivate natural toxins that are a part of bee venom and some snake venoms [8], as well as interact with some pharmacological substances [9, 10], was shown.

The effects of heparin are due to various mechanisms. In particular, it was shown that many of these effects are associated with the ability to modulate the level of calcium ions $\left(\mathrm{Ca}^{2+}\right)$ [11]. The process of the intracellular $\mathrm{Ca}^{2+}$ level increase is due to the fact that, because of the activation of phospholipase $\mathrm{C}$, the hydrolysis of phosphoinositides occurs, as a result inositol-1,4,5-triphosphate (Ins3P) is formed which mobilizes the release of intracellular $\mathrm{Ca}^{2+}[12,13]$. Many effects of $\mathrm{Ca}^{2+}$ are mediated by the protein calmodulin the level of which can increase $\mathrm{cAMP}$, which leads to an even greater release of $\mathrm{Ca}^{2+}$ from intracellular reservoirs [11]. Heparin has a pronounced hyperpolarizing effect and can change the membranes' charge, thus modulating the action of calcium channels and regulating the level of free calcium ions which are one of the most important inducers of intracellular $\mathrm{Ca}^{2+}$ release [14].

In addition, it was revealed that heparin could form complexes with various compounds. Heparin is capable of complexing with positively charged metal ions, as well as cations, including organic ones: $\mathrm{K}^{+}, \mathrm{Na}^{+}, \mathrm{Ca}^{2+}, \mathrm{Ba}^{2+}, \mathrm{Cu}^{2+}, \mathrm{Cl}^{-}, \mathrm{SO}_{4}{ }^{2-}, \mathrm{PO}_{4}{ }^{3-}$, $\mathrm{CH}_{3} \mathrm{COO}^{-}[15,16]$. The ability of heparin to form complexes with a wide range of amino acids, proteins, peptides, enzymes, and cationic compounds has been proven, while both its own properties and the properties of substances interacting with it can change [17-21]. Heparin can form complexes with physiologically active peptides. The interaction of heparin with peptides can significantly affect various parts of the regulatory system. It was found that heparin influences the manifestation of some 
ологически активными пептидами. Взаимодействие гепарина с пептидами может существенным образом отражаться на различных звеньях системы регуляции. Установлено, что гепарин in vivo влияет на проявление некоторых эффектов ряда регуляторных пептидов: адренокортикотропного гормона [22], тиролиберина [23], лютеинизирующего гормона, опиоидных пептидов [24], брадикинина, инсулина [25].

При этом в научной литературе крайне мало информации об антиноцицептивном действии гепарина. Косвенные данные позволяют только предполагать наличие этих свойств.

\section{ЦЕЛЬ ИССЛЕЛОВАНИЯ}

Изучение влияния гепарина при сочетанном применении с опиоидным агонистом фентанилом на мю-рецепторы на спинальном и супраспинальном уровнях.

\section{МАТЕРИАЛЫ И МЕТОДЫ}

Исследование проводилось на 112 нелинейных лабораторных крысах-самцах массой $200 \pm 10$ г, содержащихся на общем рационе вивария. Содержание и оперативные вмешательства осуществляли в соответствии с нормативами, представленными в Guide for Care and Use of Laboratory Animals, и требованиями приказа Министерства здравоохранения РФ от 1 апреля 2016 г. № 199н «Об утверждении Правил надлежащей лабораторной практики».

В работе исследовали следующие препараты: 1) высокомолекулярный гепарин, производства ФГУП «Московский эндокринный завод», содержащий в 1 мл раствора $5000 \mathrm{ME}$ (1 ME = 0.0077 мг); 2) фентанил, производства ФГУП «Московский эндокринный завод», содержащий в 1 мл раствора 0.05 мг сухого вещества, являющийся агонистом мю-рецепторов [26]; 3) протамина сульфат, производства ФГУП «Московский эндокринный завод», содержащий в 1 мл раствора 10 мг сухого вещества, являющегося блокатором гепарина [27]; 4) налоксон, производства фармацевтического завода «Польфа» (Польша), 0.4 мг/мл, являющийся антагонистом опиоидных рецепторов [28]. Исследуемые вещества вводили внутрибрюшинно в объеме 1 мл в определенной последовательности, предусмотренной условиями опыта. Время между введениями было постоянным и составляло 10 мин.

В качестве объекта исследования влияния гепарина на чувствительность опиоидных рецепторов использовалась эндогенная ноцицептивная система. Ноцицептивные реакции оценивали по effects of a number of regulatory peptides in vivo: adrenocorticotropic hormone [22], thyroliberin [23], luteinizing hormone, opioid peptides [24], bradykinin, insulin [25].

At the same time, there is very little information on the antinociceptive effect of heparin in the scientific literature. Indirect data allow us only to assume the presence of these properties.

\section{AIM OF THE RESEARCH}

To study the effect of heparin in combination with the opioid agonist fentanyl on mu-receptors at the spinal and supraspinal levels.

\section{MATERIALS AND METHODS}

The study was carried out on 112 outbred laboratory male rats weighing $200 \pm 10 \mathrm{~g}$, kept on the standard diet of the vivarium. Animal management and surgical interventions were carried out in accordance with the Guide for the Care and Use of Laboratory Animals, and the order of the Ministry of Health of the Russian Federation of April 1, 2016 No. 199n "On the approval of the Rules of good laboratory practice."

The following drug preparations were studied in the experiment: 1) high molecular weight heparin, produced by the Moscow Endocrine Plant, containing $5000 \mathrm{IU}$ in $1 \mathrm{ml}$ of solution ( $1 \mathrm{IU}=0.0077 \mathrm{mg}$ ); 2) fentanyl, produced by the Moscow Endocrine Plant, containing $0.05 \mathrm{mg}$ of dry matter in $1 \mathrm{ml}$ of solution, which is an agonist of mu-receptors [26]; 3) protamine sulfate, produced by the Moscow Endocrine Plant, containing $10 \mathrm{mg}$ of dry matter in 1 $\mathrm{ml}$ of solution, which is a heparin blocker [27]; 4) naloxone, produced by the Polfa S.A. (Poland), 0.4 $\mathrm{mg} / \mathrm{ml}$, which is an antagonist of opioid receptors [28]. The studied substances were injected intraperitoneally in a volume of $1 \mathrm{ml}$ in a certain sequence, provided for by the conditions of the experiment. The time between injections was constant and amounted to $10 \mathrm{~min}$.

The endogenous nociceptive system was used as an object of study of the effect of heparin on the sensitivity of opioid receptors. Nociceptive reactions were assessed by 2 standard tests, which allow to partly estimate the nature of the effect of substances mainly at the spinal (tail flick test (test I)) and supraspinal (hot plate test (test II)) levels [29]. The experiments were carried out on animals that underwent baseline testing, the initial nociceptive thresholds (baseline data) of which did not exceed $8 \mathrm{~s}$ in test I and $15 \mathrm{~s}$ in test II. 
2 стандартным тестам, позволяющим до определенной степени судить о характере влияния веществ преимущественно на спинальном (тест отведения хвоста - tail flick (тест I)) и супраспинальном (тест «горячей пластины» - hot plate (тест II)) уровнях [29]. Опыты проводили на животных, прошедших фоновое тестирование, исходные ноцицептивные пороги (фон) которых в тесте I не превышали 8 с, в тесте II - 15 с.

Тест I основан на рефлекторной реакции отведения хвоста в ответ на нанесение болевого стимула в область верхней трети хвоста. Установка представляет собой следующее. Внутрь специального футляра $(37$ × 20 × 10 см) помещался источник теплового излучения (кинопроекционная лампа со встроенным отражателем типа К21-150). Питание осуществлялось от источника постоянного тока с напряжением 4.5 В при токе в 2.7 А. Встроенный отражатель лампы позволяет получить сфокусированный световой поток, диаметр светового пятна составляет 6 мм. Температура в фокусе пучка устанавливалась на значениях, вызывающих у контрольных животных четкую аверсивную реакцию отведения хвоста с латентным периодом 5-8 с. Фокус светового пятна совпадал с отверстием на поверхности футляра. Животное (крыса) вручную фиксировалось на операционном поле футляра и на каретке подводилось к области светового пятна. Латентный период реакции отведения хвоста (ЛП РОХ) оценивался по секундомеру.

При оценке ноцицептивной реакции на супраспинальном уровне использовался тест II. Животное помещали на пластину, нагретую до 57-58 ${ }^{\circ} \mathrm{C}$, температура поверхности пластины регулировалась термостатом. По секундомеру засекалось время от момента помещения животного на пластину до момента первого облизывания лап (задних), что и составляло латентный период реакции облизывания лапок (ЛП РОЛ). Максимальное время нахождения животного на пластине - 25 с. Анальгетический эффект оценивался в процентах от значений контрольной группы, принимаемой за $100 \%$.

Взаимодействие гепарина с исследуемыми веществами in vitro изучали фотоколориметрическим методом, а также по изменению спектров поглощения данных веществ и их смесей в УФобласти. Колориметрирование осуществляли на фотоэлектроколориметре КФК-3 с использованием синего светофильтра (400 нм).

Измерения спектров поглощения в УФобласти проводили на установке, функционально идентичной однолучевому спектрофотометру. Установка включала в себя источник света (водо-
Test I is based on the tail withdrawal in response to a pain stimulus to the upper third of the tail. Test facility is as follows. A source of thermal radiation (a cinema projection lamp with a built-in reflector, type K21-150) was placed inside a special case $(37 \times 20 \times 10 \mathrm{~cm})$. Power was supplied from a direct current source with a voltage of $4.5 \mathrm{~V}$ and amperage of 2.7 A. The built-in lamp reflector gives a focused luminous flux with the diameter of the light spot being $6 \mathrm{~mm}$. The temperature at the focus of the beam was set at the values causing a distinct aversive tail flick reaction in control animals with a latency of 5-8 s. The focus of the light spot coincided with the hole on the surface of the case. The animal (rat) was manually fixed on the operating field of the case and was brought to the area of the light spot on the carriage. The tail flick latency (TFL) was estimated using a stopwatch timer.

Test II was used to assess the nociceptive response at the supraspinal level. The animal was placed on a plate heated to $57-58^{\circ} \mathrm{C}$; the plate surface temperature was controlled by a thermostat. The stopwatch timer was used to record the time from the moment the animal was placed on the plate until the moment of the first paw licking (hind legs), which constituted the paw licking latency (PLL). The maximum time an animal was on the plate reached $25 \mathrm{~s}$. The analgesic effect was assessed as a percentage of the values of the control group, taken as $100 \%$.

The interaction of heparin with the test substances in vitro was studied by the photocolorimetric method, as well as by changes in the absorption spectra of these substances and their mixtures in the ultraviolet. Colorimetry was carried out on a KFK-3 photoelectric colorimeter using a blue light filter (400 $\mathrm{nm})$.

Measurements of absorption spectra in the UV were carried out on an apparatus functionally identical to a single-beam spectrophotometer. The apparatus included a light source (hydrogen lamp or incandescent lamp), a MDR-12 monochromator with a stepping motor, a synchronous detector, a light-receiving chamber in which quartz cuvettes with solutions were located, and a photomultiplier connected to a computer for automatic data recording. The test substances were diluted in phosphate buffer ( $\mathrm{pH}$ 7.2) or in distilled water, the extinction of solutions was measured with reference to solvents.

The significance of differences between groups was assessed directly by the variant values using 
родная лампа или лампа накаливания), монохроматор МДР-12 с шаговым двигателем, синхронный детектор, светоприемную камеру, в которой размещались кварцевые кюветы с растворами, и фотоумножитель, подключенный к компьютеру для автоматической регистрации данных. Исследуемые вещества разводили в фосфатном буфере (pH 7.2) или в дистиллированной воде, экстинкцию растворов измеряли относительно растворителей.

Достоверность различий между группами оценивалась непосредственно по значениям вариант с использованием непараметрического критерия Уилкоксона - Манна - Уитни для независимых совокупностей. Для множественных сравнений применяли критерий Данна [30]. Все экспериментальные работы проводились с учетом этических норм обращения с животными и отвечали требованиям Общества защиты животных [31, 32].

\section{РЕЗУЛЬТАТЫ И ОБСУЯДЕНИЕ}

Установлено, что внутрибрюшинное введение фентанила в дозе 0.1 мг/кг достоверно увеличивает длительность латентных периодов (ЛП) болевых реакций на спинальном уровне, особенно в течение первых 40 мин от момента введения, при этом ЛП РОХ превышает контрольные величины в 2-3 раза. Затем следует снижение антиноцицептивной реакции, и к 120-й мин ЛП РОХ возвращается к контрольным величинам. При регистрации болевой реакции на супраспинальном уровне максимальное увеличение ЛП РОЛ регистрируется на 150-180-й мин от момента инъекции (табл. 1).

При предварительном введении гепарина в дозах 50, 500 и $5000 \mathrm{ME} /$ кг с последующей инъекцией фентанила в дозе 0.1 мг/кг в первые 40 мин наблюдается увеличение ЛП РОХ в 3-5 раз относительно контроля и в 1.5 раза относительно введения только фентанила. Следует отметить, что повышение порога болевой чувствительности имеет продолжительный характер и его снижение фиксируется на 150-180-й мин от момента инъекции (см. табл. 1).

Несколько иная картина наблюдается при оценке антиноцицептивной реакции на супраспинальном уровне. При тех же условиях опыта, при которых регистрировали ЛП РОХ, латентный период РОЛ при действии фентанила на фоне возрастающих доз гепарина достигает максимальных значений к 150-180-й мин от момента инъекции, в то время как ЛП РОХ в этот временной период снижается до контрольных величин (см. табл. 1). the Wilcoxon-Mann-Whitney nonparametric test for independent populations. Dunn's test was used for multiple comparisons [30]. All experimental work was carried out taking into account the ethical standards of treatment of animals and met the requirements of the Society for the Protection of Animals [31, 32].

\section{RESULTS AND DISCUSSION}

It was found that intraperitoneal administration of fentanyl at a dose of $0.1 \mathrm{mg} / \mathrm{kg}$ significantly increases the duration of latencies (L) of pain reactions at the spinal level, especially during the first 40 min from the moment of administration, while TFL exceeds the control values by $2-3$ times. This is followed by a decrease in the antinociceptive response, and TFL returns to the control values by the $120^{\text {th }}$ min. When registering a pain reaction at the supraspinal level, the maximum increase of the PLL is recorded at $150-180^{\text {th }}$ min from the moment of injection (Table 1).

With pre-administration of heparin at doses of 50,500 , and $5000 \mathrm{IU} / \mathrm{kg}$ followed by the injection of fentanyl at a dose of $0.1 \mathrm{mg} / \mathrm{kg}$ in the first $40 \mathrm{~min}$, an increase of TFL is observed by 3-5 times relative to the control, and 1.5 times relative to the administration of fentanyl alone. It should be noted that the increase in the pain threshold has a long-term character, and its decrease is recorded at $150-180^{\text {th }}$ min from the moment of injection (see Table 1).

A somewhat different picture is observed when assessing the antinociceptive response at the supraspinal level. Under the same experimental conditions as with the TFL recording, the latency of PL reflex under the action of fentanyl together with the increasing doses of pre-administered heparin, reaches its maximum values by $150-180^{\text {th }}$ min from the moment of injection, while the TFL at this time period decreases to the control values (see Table 1).

The antinociceptive effect of fentanyl is reduced at both spinal and supraspinal levels by pre-administration of the opioid receptor blocker naloxone. At the spinal level, the TFL consistently decreases with time elapsed from the moment of administration, and by the $180^{\text {th }}$ min it approaches the sub-control values. At the supraspinal level, the opposite picture is observed: the PLL increases by the end of the observation, amounting to $187.1 \%$ by the $150^{\text {th }}$ min, which is significantly higher than the control values, the PLL values with the injection of fentanyl and TFL in the naloxone $\rightarrow$ fentanyl series. The administration of the test substances ac- 
Таблица 1. Модуляция гепарином и налоксоном (1 мг/кг) антиноцицептивного действия фентанила (о.1 мг/кг) на спинальном и супраспинальном уровнях, \%

Table 1. Modulation by heparin and naloxone $(1 \mathrm{mg} / \mathrm{kg})$ of the antinociceptive action of fentanyl (o.1 mg/kg) at the spinal and supraspinal levels, \%

\begin{tabular}{|c|c|c|c|c|c|c|c|}
\hline \multirow[t]{2}{*}{ Условия опыта / Experimental conditions } & \multicolumn{5}{|c|}{$\begin{array}{l}\text { Время после введения веществ, мин } \\
\text { Time after administration of substances, min }\end{array}$} & \multirow[b]{2}{*}{150} & \multirow[b]{2}{*}{180} \\
\hline & 20 & 40 & 60 & 90 & 120 & & \\
\hline Контроль (физиол. p-p) / Control (saline) & 100 & 100 & 100 & 100 & 100 & 100 & 100 \\
\hline $\begin{array}{l}\text { Фентанил / Fentanyl: } \\
\text { ЛП РОХ / TFL } \\
\text { ЛП РОЛ / PLL }\end{array}$ & $\begin{array}{l}304.6^{* \bullet} \\
118.2^{\bullet}\end{array}$ & $\begin{array}{l}247.2^{*} \\
155 \cdot 6^{* \bullet}\end{array}$ & $\begin{array}{l}119.1 \\
118.5\end{array}$ & $\begin{array}{l}155 \cdot 3^{*} \\
110.4^{\bullet}\end{array}$ & $\begin{array}{l}108.1 \\
77.7^{* \bullet}\end{array}$ & $\begin{array}{l}94.9 \\
162.2^{* \bullet}\end{array}$ & $\begin{array}{l}98.4 \\
166.7^{* \bullet}\end{array}$ \\
\hline $\begin{array}{l}\text { Гепарин }(50 \mathrm{ME} / \text { к) } \rightarrow \text { фентанил: } \\
\text { Heparin }(50 \text { IU/kg) } \rightarrow \text { fentanyl: } \\
\text { ЛП РОX / TFL } \\
\text { ЛП РОЛ / PLL }\end{array}$ & $\begin{array}{l}300.3^{*} \\
158.4^{\bullet}\end{array}$ & $\begin{array}{l}286.2^{* \star} \\
168.8^{* \bullet}\end{array}$ & $\begin{array}{l}160.8^{*} \\
122.3\end{array}$ & $\begin{array}{l}168.1^{*} \\
119.4^{\bullet}\end{array}$ & $\begin{array}{l}232.5^{* \star} \\
84.9^{\bullet}\end{array}$ & $\begin{array}{l}116.3 \\
158.8^{* \bullet}\end{array}$ & $\begin{array}{l}98.8 \\
174.7^{* \bullet}\end{array}$ \\
\hline $\begin{array}{l}\text { Гепарин }(500 \mathrm{ME} / \text { кг }) \rightarrow \text { фентанил: } \\
\text { Hераrin }(500 \text { IU/kg) } \rightarrow \text { fentanyl: } \\
\text { ЛП РОХ / TFL } \\
\text { ЛП РОЛ / PLL }\end{array}$ & $\begin{array}{l}496.1^{* \star} \\
208.7^{* \star \bullet}\end{array}$ & $\begin{array}{l}478.5^{\star \star} \\
101.5^{\star \bullet}\end{array}$ & $\begin{array}{l}275.2^{* \star} \\
192.1^{* \star \bullet}\end{array}$ & $\begin{array}{l}244 \cdot 3^{* \star} \\
115 \cdot 6^{\bullet}\end{array}$ & $\begin{array}{l}158.6^{* \star} \\
73.2^{* \bullet}\end{array}$ & $\begin{array}{l}106.4 \\
160.7^{* \bullet}\end{array}$ & $\begin{array}{l}96.8 \\
164.9^{* \bullet}\end{array}$ \\
\hline $\begin{array}{l}\text { Гепарин }(5000 \mathrm{ME} / \text { кг) } \rightarrow \text { фентанил: } \\
\text { Hераrin }(5000 \text { IU } / \mathrm{kg}) \rightarrow \text { fentanyl: } \\
\text { ЛП РОХ / TFL } \\
\text { ЛП РОЛ / PLL }\end{array}$ & $\begin{array}{l}420.4^{* \star} \\
171.7^{* \star \bullet}\end{array}$ & $\begin{array}{l}412.3^{* \star} \\
218 \cdot 9^{* \star \bullet}\end{array}$ & $\begin{array}{l}225.8^{* \star} \\
138.8^{* \bullet}\end{array}$ & $\begin{array}{l}273.8^{* \star} \\
131.1^{* \bullet}\end{array}$ & $\begin{array}{l}408.6^{* \star} \\
109.5^{\circ}\end{array}$ & $\begin{array}{l}210^{* \star} \\
242.5^{* \star}\end{array}$ & $\begin{array}{l}88.7 \\
220.9^{* \star \bullet}\end{array}$ \\
\hline $\begin{array}{l}\text { Налоксон } \rightarrow \text { фентанил / Naloxone } \rightarrow \text { fentanyl } \\
\text { ЛП РОХ / TFL } \\
\text { ЛП РОЛ / PLL }\end{array}$ & $\begin{array}{l}121.6^{* \star} \\
97.4^{\bullet}\end{array}$ & $\begin{array}{l}158.1^{* \star} \\
95.5^{\star \ll \bullet}\end{array}$ & $\begin{array}{l}146.3^{* \star} \\
110.6^{\bullet}\end{array}$ & $\begin{array}{l}82.3^{\star} \\
131.5^{\circ}\end{array}$ & $\begin{array}{l}134.2^{* \star} \\
118.2^{\star}\end{array}$ & $\begin{array}{l}102.6 \\
187.1^{* \star \bullet}\end{array}$ & $\begin{array}{l}71.5 \\
140.0^{* \star \bullet}\end{array}$ \\
\hline $\begin{array}{l}\text { Налоксон } \rightarrow \text { гепарин } \rightarrow \text { фентанил: } \\
\text { Naloxone } \rightarrow \text { heparin } \rightarrow \text { fentanyl: } \\
\text { ЛП POX / TFL } \\
\text { ЛП РОЛ / PLL }\end{array}$ & $\begin{array}{l}119.3^{\star} \\
102.6^{\star}\end{array}$ & $\begin{array}{l}148.1^{* \star} \\
103.4^{\star \bullet}\end{array}$ & $\begin{array}{l}157.1^{* \star} \\
114.1^{\circ}\end{array}$ & $\begin{array}{l}148.7^{* / k} \\
123.3^{*}\end{array}$ & $\begin{array}{l}145 \cdot 9^{* \star} \\
65 \cdot 5^{* \bullet}\end{array}$ & $\begin{array}{l}140.0^{* *} \\
150.0^{*}\end{array}$ & $\begin{array}{l}109.9 \\
153.3^{* \bullet}\end{array}$ \\
\hline $\begin{array}{l}\text { Протамина сульфат (10 мг/кг) } \rightarrow \text { фентанил: } \\
\text { Protamine sulfate }(10 \mathrm{mg} / \mathrm{kg}) \rightarrow \text { fentanyl : } \\
\text { ЛП РОX / TFL } \\
\text { ЛП РОЛ / PLL }\end{array}$ & $\begin{array}{l}108.5^{\star} \\
102.2\end{array}$ & $\begin{array}{l}110.2^{\star} \\
103.2^{\star}\end{array}$ & $\begin{array}{l}118.9 \\
112.4\end{array}$ & $\begin{array}{l}112.0^{\star} \\
117.3\end{array}$ & $\begin{array}{l}101.1 \\
64.8^{\star \bullet}\end{array}$ & $\begin{array}{l}74 \cdot 6^{* \ll \star} \\
135 \cdot 1^{* \star \bullet}\end{array}$ & $\begin{array}{l}89.3^{*} \\
130.2^{* \star \bullet}\end{array}$ \\
\hline
\end{tabular}

* Различия статистически значимы по сравнению с контролем $(p<0.05)$.

The differences are statistically significant compared to the control $(p<0.05)$.

* Различия статистически значимы по сравнению с серией «Фентанил» $(p<0.05)$.

The differences are statistically significant compared to the fentanyl series $(p<0.05)$.

• Различия статистически значимы между ЛП РОХ и ЛП РОЛ.

The differences are statistically significant between the TFL and the PLL.

Антиноцицептивный эффект фентанила снижается на фоне предварительного введения блокатора опиоидных рецепторов налоксона как на спинальном, так и на супраспинальном уровнях. На спинальном уровне ЛП РОХ последовательно снижается с течением времени, прошедшего от момента введения, и к 180-й мин приближается к субконтрольным величинам. На супраспинальном уровне наблюдается обратная картина: ЛП РОЛ возрастает к концу наблюдения, составляя к 150-й мин $187.1 \%$, что достоверно выше контрольных величин, значений ЛП РОЛ при введении фентанила и ЛП РОХ в серии «Налоксон $\rightarrow$ фентанил». Введение исследуемых веществ по схеме «Налоксон $\rightarrow$ гепарин $\rightarrow$ фентанил» в определенной степени нивелировало антагонистическое действие налоксона на опиоид- cording to the naloxone $\rightarrow$ heparin $\rightarrow$ fentanyl series neutralized the antagonistic effect of naloxone on opioid receptors to a certain extent, however, neither TFL, nor PLL reached the values obtained with the injection of fentanyl alone (see Table 1).

In the series of experiments with registration of the antinociceptive effect of fentanyl at the spinal and supraspinal levels, the role of endogenous heparin in the realization of the mu-opioid receptors agonist action is especially pronounced. Thus, the blockade of endogenous heparin with protamine sulfate at a dose of $10 \mathrm{mg} / \mathrm{kg}$ is accompanied by a sharp decrease in TFL and PLL, which indicates the undoubted role of endogenous heparin in the implementation of the antinociceptive phenomenon of fentanyl. 
ные рецепторы, однако ни ЛП РОХ, ни ЛП РОЛ не достигали значений, полученных при инъекции только фентанила (см. табл. 1).

В серии экспериментов с регистрацией антиноцицептивного действия фентанила на спинальном и супраспинальном уровнях особенно ярко проявляется роль эндогенного гепарина в реализации эффектов агониста мю-опиоидных рецепторов. Так, блокада эндогенного гепарина протамина сульфатом в дозе 10 мг/кг сопровождается резким снижением ЛП РОХ и ЛП РОЛ, что свидетельствует о несомненной роли эндогенного гепарина в реализации антиноцицептивного феномена фентанила.

Таким образом, гепарин в дозах 50, 500 и $5000 \mathrm{ME} / к г$ потенцирует антиноцицептивное действие фентанила на спинальном и супраспинальном уровне, а протамина сульфат, блокируя эндогенный гепарин, снижает противоболевой эффект агониста опиоидных рецепторов. Сходный с протамина сульфатом эффект регистрируется и при предварительном введении налоксона, однако в данном случае происходит блокада опиоидных рецепторов по пути лиганд-рецепторного взаимодействия.

Для выяснения возможного взаимодействия гепарина с фентанилом in vivo была изменена последовательность введений исследуемых веществ. Если в предыдущей серии фентанил вводился на фоне действия гепарина, то в следующей серии гепарин инъецировался в виде смеси, приготовленной in vitro при инкубации в течение 30 мин при температуре $37^{\circ} \mathrm{C}$ в соотношениях гепаринфентанил $5: 1,50: 1$ и $500: 1$ (табл. 2). В качестве контроля была выбрана концентрация гепарина $500 \mathrm{ME} / к г$, при введении которой регистриро-
Thus, heparin at doses of 50, 500, and 5000 $\mathrm{IU} / \mathrm{kg}$ potentiates the antinociceptive effect of fentanyl at the spinal and supraspinal levels, and protamine sulfate, blocking endogenous heparin, reduces the analgesic effect of an opioid receptor agonist. An effect similar to protamine sulfate is also recorded with the pre-administration of naloxone, but in this case, the blockade of opioid receptors occurs via the ligand-receptor interaction.

To elucidate the possible interaction of heparin with fentanyl in vivo, the sequence of the test substances administration was changed. If in the previous series fentanyl was administered in presence of the heparin action, then in the next series heparin was injected in the form of a mixture prepared in vitro during 30 min incubation at $37^{\circ} \mathrm{C}$ at the heparin-fentanyl ratios of $5: 1,50: 1$, and $500: 1$ (Table 2). As a control, the concentration of heparin of $500 \mathrm{IU} / \mathrm{kg}$ was chosen, the introduction of which showed the effects of maximum severity in the previous heparin $(500 \mathrm{IU} / \mathrm{kg}) \rightarrow$ fentanyl series (see Table 1).

It should be noted that heparin at a dose of 500 $\mathrm{IU} / \mathrm{kg}$ also has an antinociceptive effect at the spinal level. The latency of tail flick reaction significantly differs from the control when registered at $40^{\text {th }}, 60^{\text {th }}$ and $120^{\text {th }}$ min from the moment of injection (see Table 2).

Comparative characteristics of the two methods of administration of the studied compounds showed that in both cases the heparin potentiation of the antinociceptive action of fentanyl takes place. It is known from the literature [13] that when heparin interacts with bioactive substances, their

Таблица 2. Модуляция гепарином антиноцицептивного действия фентанила (о.1 мг/кг) на спинальном (ЛП POX) уровне, \%

Table 2. Heparin modulation of the antinociceptive action of fentanyl (0.1 mg/kg) at the spinal (TFL) level, \%

\begin{tabular}{|c|c|c|c|c|c|c|c|}
\hline \multirow[t]{2}{*}{ Условия опыта / Experimental conditions } & \multicolumn{7}{|c|}{$\begin{array}{l}\text { Время после введения веществ, мин } \\
\text { Time after administration of substances, min } \\
\end{array}$} \\
\hline & 20 & 40 & 60 & 90 & 120 & 150 & 180 \\
\hline Контроль (физиол. p-p) / Control (saline) & 100 & 100 & 100 & 100 & 100 & 100 & 100 \\
\hline Гепарин (50о ME/кг) / Heparin (50о IU/kg) & 94.2 & $125.2^{*}$ & $173 \cdot 3^{*}$ & 88.4 & $169.2^{*}$ & 101.7 & 86.9 \\
\hline Фентанил (о.1 мг/кг) | Fentanyl (o.1 mg/kg) & $298.1^{*}$ & $230.8^{*}$ & 110.0 & $145.2^{*}$ & 101.8 & 90.9 & 98.4 \\
\hline Гепарин + фентанил / Heparin + fentanyl (5: 1) & $269.8^{*}$ & $275 \cdot 7^{* \star}$ & $257.8^{* \star}$ & $251.3^{* \star}$ & $171.0^{* \star}$ & 105.5 & 96.7 \\
\hline Гепарин + фентанил / Heparin + fentanyl (50 : 1) & $480.0^{* \star}$ & $485 \cdot 4^{* \star}$ & $300^{* \star}$ & $269.2^{* \star}$ & $371.8^{* \star}$ & $161.4^{* \star}$ & 96.7 \\
\hline Гепарин + фентанил / Heparin + fentanyl (500 : 1) & $406.8^{* \star}$ & $407.7^{* \star}$ & $355 \cdot 5^{* \star}$ & $215 \cdot 4^{* \star}$ & $405.1^{* \star}$ & $200^{* \star}$ & 88.7 \\
\hline
\end{tabular}

* Различия статистически значимы по сравнению с контролем ( $p<0.05)$.

The differences are statistically significant compared to the control $(p<0.05)$.

^ Различия статистически значимы по сравнению с серией «Фентанил» $(p<0.05)$

The differences are statistically significant compared to the Fentanyl series $(p<0.05)$. 
валась максимальная выраженность эффектов в предыдущей серии «Гепарин (50о ME/кг) $\rightarrow$ фентанил» (см. табл. 1).

Следует отметить, что гепарин в дозе 500 ME/кг также обладает антиноцицептивным действием на спинальном уровне. Латентный период реакции отведения хвоста достоверно отличается от контроля при регистрации на 40-й, 60-й и 120-й мин от момента введения (см. табл. 2).

Сравнительная характеристика двух способов введения исследуемых веществ показала, что и в том и в другом случае имеет место потенцирование гепарином антиноцицептивного действия фентанила. Из литературы известно [13], что при взаимодействии гепарина с биологически активными веществами их активность изменяется в ту или другую сторону. Опираясь на полученные данные по предварительному и одновременному введению гепарина, можно предполагать, что комплексообразования между фентанилом и гепарином не происходит. Это предположение подкрепляется колориметрическим и спектрофотометрическим исследованием in vitro смеси гепаринфентанил в соотношении $5: 1,50: 1$ и $500: 1$. Фотоэлектроколориметрическое исследование смеси гепарин-фентанил не выявило изменений оптической плотности относительно контроля, в качестве которого использовался раствор гепарина в концентрациях 50, 500 и $5000 \mathrm{ME} / к г$. Анализ спектров поглощения в УФ-области показал, что фентанил в концентрации о.1 мг/мл характеризуется крутым пиком поглощения в области 0.210 мкм (рис. 1). Амплитуда пика не меняется при исследовании смеси гепарин-фентанил независимо от концентрации использованного гепарина и имеет однотипную кривую, которая для наглядности на рис. 1 представлена для смеси гепарин-фентанил (5 : 1). Опираясь на предыдущие данные, можно предполагать, что фентанил не взаимодействует in vitro с гепарином (см. рис. 1).

Агонист мю-опиоидных рецепторов фентанил обладает ярко выраженным антиноцицептивным действием на спинальном и супраспинальном уровне, на что указывает снижение величины ЛП РОХ и ЛП РОЛ при предварительном введении антагониста опиоидных рецепторов - налоксона. Анальгезия, связанная с действием агонистов, обусловлена формированием лиганд-рецепторного комплекса, в котором в качестве лиганда выступает фентанил [26].

Гепарин в дозе $500 \mathrm{ME} / к г$ также обладает противоболевым действием, однако этот эффект значительно слабее, чем у фентанила. При термическом болевом воздействии на эксперимен- activity changes in one direction or another. Based on the data for the pre- and simultaneous administration of heparin, it can be assumed that complexing reaction between fentanyl and heparin does not occur. This assumption is supported by colorimetric and spectrophotometric studies in vitro of the heparin-fentanyl mixture at the ratios of $5: 1$, $50: 1$, and $500: 1$. Photoelectrocolorimetric study of a mixture of heparin-fentanyl did not reveal changes in the optical density relative to the control, which was a solution heparin at concentrations of 50, 500, and $5000 \mathrm{IU} / \mathrm{kg}$. Analysis of the UV absorption spectra has shown that fentanyl at a concentration of $0.1 \mathrm{mg} / \mathrm{ml}$ is characterized by a steep absorption peak in the range of $0.210 \mu \mathrm{m}$ (Fig. 1). The peak amplitude does not change in the study of the heparin-fentanyl mixture, regardless of the heparin concentration used and has the same type of curve, which for clarity is shown for a mixture of heparin-fentanyl at the ratio $5: 1$ (see Fig. 1). Based on previous data, it can be assumed that fentanyl does not interact in vitro with heparin (see Fig. 1).

The mu-opioid receptor agonist fentanyl has a pronounced antinociceptive effect at the spinal and supraspinal levels, as indicated by a decrease in the TFL and PLL values with the pre-administration of the opioid receptor antagonist naloxone. Analgesia associated with the action of agonists is due to the formation of a ligand-receptor complex in which fentanyl acts as a ligand [26].

Heparin at a dose of $500 \mathrm{IU} / \mathrm{kg}$ also has an analgesic effect, but this effect is much weaker than that of fentanyl. On exposure to the thermal painful effects, when the nociceptive system of the experimental animals is activated, a stress response to this type of irritation is formed [33]. One of the components of the mechanism of the antistress heparin action is its antinociceptive effect revealed in our experiments [34].

The heparin relationships with mediator systems, including receptors, are of greater interest. It turned out that heparin affects the desensitization of opioid receptors, in an uncompetitive way inhibits the binding of the $3 \mathrm{H}^{+}-\mathrm{N}$-allyl normetazocine opioids to sigma receptor in the microsomal fraction of rat brain and liver membranes. Heparin downregulates the phosphorylation of G-protein coupled opioid receptors (GPCR), and, as a consequence, reduces hyposensitization caused by the specific opioid agonist etorphin and D-Ala2-DLeu5-enkephalin (DADLE); blocks the release of $\mathrm{Ca}^{2+}[24,35]$; like inositol-1,4,5-trisphosphate in- 

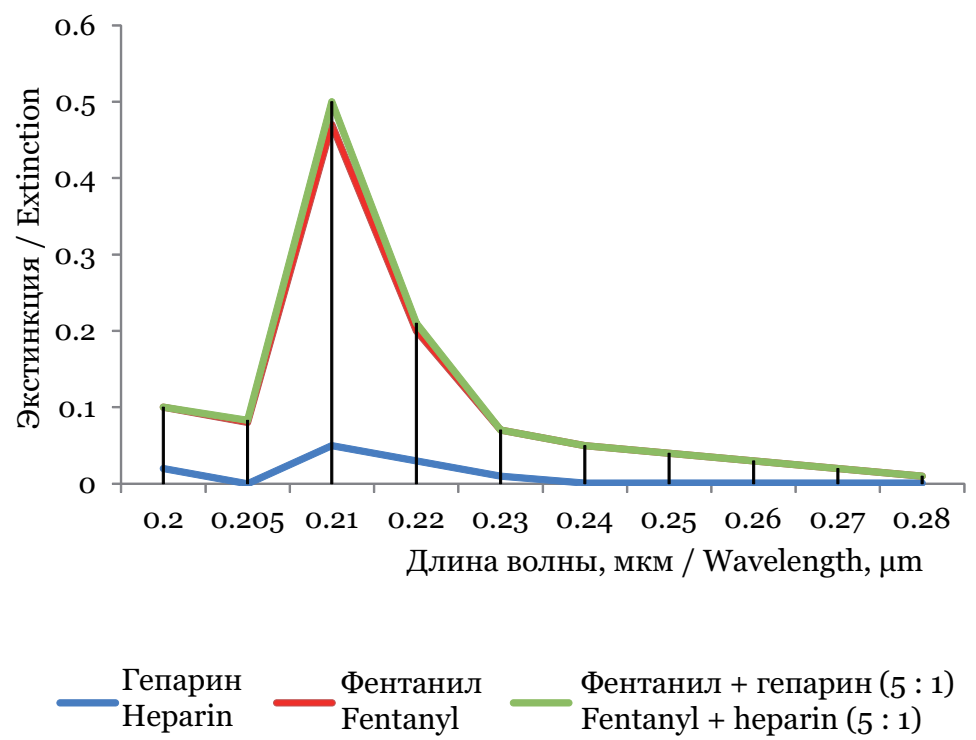

Рис. 1. Спектры поглощения фентанила, гепарина и их смеси в УФ-области Fig. 1. UV absorption spectra of fentanyl, heparin and their mixtures

тальных животных, когда активируется ноцицептивная система организма, формируется стрессреакция на данный вид раздражения [33]. Одним из компонентов механизма антистрессорного эффекта гепарина является обнаруженное в наших экспериментах антиноцицептивное действие этого препарата [34].

Больший интерес представляют взаимоотношения гепарина с медиаторными системами, в том числе и с рецепторами. Оказалось, что гепарин влияет на десенситизацию опиоидных рецепторов, подавляет неконкурентным способом связывание с сигма-рецептором опиоидов $3 \mathrm{H}^{+}-\mathrm{N}$-аллилнорметазоцина в микросомальной фракции мозга и мембран печени крыс. Гепарин уменышает фосфорилирование опиоидных рецепторов, соединенных с G-белком (GPCR), и, как следствие, снижает гипосенсибилизацию, вызванную специфическим опиоидным агонистом эторфином и D-Ala - D-Leu - -энкефалином (DADLE); блокирует выход $\mathrm{Ca}^{2+}[24,35]$; как и ингибитор инозитол-1,4,5-трисфосфат, гепарин тормозит развитие морфиновой толерантности. Развитие десенситизации, т. е. уменьшение чувствительности (гипосенситизация) и сокращение числа рецепторов на клеточной поверхности (интернализация), выявлено не только для опиоидных рецепторов, но и для других, также принадлежащих к GPCR, в частности $\beta 2-$ и a2-адренергических, для А1-аденозиновых и м2мускариновых рецепторов [26]. Недавно были изучены рецепторы FMRFa-пептидов [36], они так- hibitor, heparin hampers the development of morphine tolerance. The desensitization enhancement, i.e. a decrease in sensitivity (hyposensitization) and a decrease in the number of receptors on the cell surface (internalization), was revealed not only for opioid receptors, but for the others also belonging to the GPCR, in particular $\beta 2$ - and $\alpha_{2}$-adrenergic, as well as A1-adenosine and m2-muscarinic receptors [26]. Recently FMRFa-peptide receptors have been studied [36]; they also belong to the GPCR class. Heparin is a non-specific protein kinase blocker for opioid and $\beta$-adrenergic receptors. Perhaps, interacting with this type of receptor, heparin inhibits the desensitization process caused by the action of synthetic agonists, thereby increasing the sensitivity of the receptors to analgesics, as a result of which a lower dose is required to prolong the effect.

The study showed that heparin enhances the analgesic activity of the opioid agonist fentanyl in the tail flick test and paw licking test. This phenomenon has a multicomponent character since it involves both opioid and adrenergic mechanisms which are possibly separated in time. High heparin level is a necessary condition for the long-term functioning of the system through which the analgesic effect of opioid agonists is realized. It can be assumed that the endogenous heparin, the release of which occurs upon activation of the adrenergic system, affects the receptors of the opioid system and does not determine the interaction with the opioid agonist. 
же относятся к классу GPCR. Гепарин является неспецифическим блокатором протеинкиназы для опиоидных и $\beta$-адренергических рецепторов. Возможно, взаимодействуя с данным видом рецепторов, гепарин тормозит процесс десенситизации, вызванный воздействием синтетических агонистов, тем самым повышая чувствительность рецепторов к анальгетикам, вследствие чего требуется меньшая доза для продления эффекта.

Проведенное исследование показало, что гепарин усиливает анальгетическую активность опиоидного агониста - фентанила в тесте отведения хвоста и облизывания лап. Данное явление носит многокомпонентный характер, поскольку в нем задействованы как опиоидные, так и адренергические механизмы, которые, возможно, разобщены во времени. Повышенное содержание гепарина - необходимое условие длительного функционирования системы, через которую реализуется обезболивающее действие опиоидных агонистов. Можно предположить, что эндогенный гепарин, выброс которого происходит при активации адренергической системы, воздействует на рецепторы опиодной системы и не определяет взаимодействие с опиодным агонистом.

Высокий уровень различий ЛП $\mathrm{POX}$ и ЛП РОЛ, возможно, связан с тем, что анальгезия на супраспинальном уровне обусловлена $\mu_{1}$-опиоидными рецепторами, а на спинальном уровне $-\mu_{2}$-рецепторами [26].

\section{ЗАКЛЮЧЕНИЕ}

Полученные экспериментальные данные позволяют говорить о сенсибилизирующем действии гепарина на мю-опиоидные рецепторы, инициированные агонистом - фентанилом, на

\section{СПИСОК ЛИТЕРАТУРЫ}

1. Кондашевская М.В., Кудрин В.С., Клодт П.М. Новые аспекты действия гепарина // Бюл. эксперимент. биологии и медицины. 2000. Т. 130, № 12. C. 613-616.

2. Mishra-Gorur K., Castellot J.J., jr. Heparin rapidly and selectively regulates protein tyrosine phosphorylation in vascular smooth muscle cells // J. Cell Physiol. 1999. Vol. 178 (2). P. 205-215.

3. Gori A.M., Pepe G., Attanasio M. et al. Tissue factor reduction and tissue factor pathway inhibitor release after heparin administration // Thromb. Haemost. 1999. Vol. 81 (4). P. 589-593.

4. Hakala J.K., Oörni K., Ala-Korpela M., Kovanen P.T. Lipolytic modification of LDL by phospholipase A2 induces particle aggregation in the absence and fusion in the presence of heparin // Arterioscler. Thromb. Vasc. Biol. 1999. Vol. 19 (5). P. 1276-1283.
The high level differences between TFL and PLL are probably due to the fact that analgesia at the supraspinal level depends on $\mu_{1}$-opioid receptors, and at the spinal level $-\mu_{2}$-receptors [26].

\section{CONCLUSION}

The obtained data allow us to speak of the sensitizing effect of heparin on the mu-opioid receptors initiated by the agonist at the spinal and supraspinal levels. The pre-administration of the opioid receptor antagonist naloxone reduces both the antinociceptive effect of fentanyl and the analgesia caused by the combined use of heparin and fentanyl. Protamine sulfate, blocking endogenous heparin, reduces the aversive reaction latency (TFL and PLL) of rats to thermal pain stimulus, which indicates the potentiating effect of endogenous heparin.

Conflict of interest. The authors declare no conflict of interest.

спинальном и супраспинальном уровнях. Предварительное введение антагониста опиоидных рецепторов налоксона снижает как антиноцицептивный эффект фентанила, так и анальгезию, вызванную сочетанным применением гепарина и фентанила. Протамин сульфат, блокируя эндогенный гепарин, снижает аверсивную реакцию (ЛП РОХ и ЛП РОЛ) крыс на термическое болевое воздействие, что говорит о потенцирующем действии эндогенного гепарина.

Конфликт интересов. Авторы заявляют об отсутствии конфликта интересов.

\section{REFERENCES}

1. Kondashevskaya M.V., Kudrin V.S., Klodt P.M. (2000). New aspects of the heparin action. Bulletin of Experimental Biology and Medicine, 130(12), 613616. In Russ.

2. Mishra-Gorur K., Castellot J.J., jr. (1999). Heparin rapidly and selectively regulates protein tyrosine phosphorylation in vascular smooth muscle cells. J. Cell Physiol., 178 (2), 205-215.

3. Gori A.M., Pepe G., Attanasio M. et al. (1999). Tissue factor reduction and tissue factor pathway inhibitor release after heparin administration. Thromb. Haemost., 81 (4), 589-593.

4. Hakala J.K., Oörni K., Ala-Korpela M., Kovanen P.T. (1999). Lipolytic modification of LDL by phospholipase A2 induces particle aggregation in the absence and fusion in the presence of heparin. Arterioscler. Thromb. Vasc. Biol., 19 (5), 1276-1283. 
5. Лукашин Б.П., Софронов Г.А. Радиозащитное действие цистамина и гепарина в опытах на мышах с различной резистентностью // Бюл. эксперимент. биологии и медицины. 1996. Т. 121, № 5. С. 544-546.

6. Lever R., Page C.P. Novel drug opportunities for heparin // Nat. Rev. Drug Discov. 2002. Vol. 1 (2). P. 140148.

7. Coombe D.R., Kett W.C. Heparan sulfate-protein interactions: therapeutic potential through structure-function insights // Cell. Mol. Life Sci. 2005. Vol. 62 (4). P. $410-424$.

8. Хомутов А.Е., Пурсанов К.А. Биологические и клинические основы апитерапии: Монография. Н. Новгород, 2011. 400 с.

9. Пурсанов К.А., Хомутов А.Е., Бутылин А.Г. Влияние гепарина на антиноцицептивные свойства окситоцина // Мед. альманах. 2009. № 4 (9). С. 198200.

10. Хомутов А.Е., Дерюгина А.В. Гепаринология: физиолого-биохимические и биомедицинские аспекты: Учеб. пособие. Н. Новгород, 2019. 620 с.

11. Yamamura H., Ohya S., Muraki K., Imaizumi Y. Involvement of inositol 1,4,5-trisphosphate formation in the voltage-dependent regulation of the $\mathrm{Ca}^{2+}$ concentration in porcine coronary arterial smooth muscle cells // J. Pharmacol. Exp. Ther. 2012. Vol. 342 (2). P. 486-496.

12. Кондашевская М.В. Современные представления о роли гепарина в гемостазе и регуляции ферментативной и гормональной активности // Вестн. PAMH. 2010. № 7. С. 35-43.

13. Кондашевская М.В. Роль гепарина в иммунных, воспалительных и репаративных процессах // Клин. и эксперимент. морфология. 2012. № 5. C. $64-70$.

14. Németh K., Kurucz I. Suppression of $\mathrm{Ca}^{2+}$ influx by unfractionated heparin in non-excitable intact cells via multiple mechanisms // Biochem. Pharmacol. 2005. Vol. 69 (6). P. 929-940.

15. Феофанова М.А., Францева Ю.В., Журавлёв Е.В., Баранова Н.В., Потеха Е.В. Химические равновесия в системе ион $\mathrm{CO}^{2+}$ - гепарин - пролин // Вестн. Тверского гос. Ун-та. 2014. № 2. С. 13-18.

16. Феофанова М.А., Францева Ю.В., Лапшин С.В. Комплексообразование в системе гепарин - ион металла // Координационная химии. 2012. Т. 38, № 5 . С. 387-392.

17. Арсютов О.В., Арсютов В.П. Роль гистамина, серотонина, катехоламинов, гепарина, ксантиноксидазы в заживлении поврежденной во время операции брюшины // Вестн. Чувашского ун-та. 2013. № 3. C. $363-368$.

18. Кудряшов Б.А. Биологические проблемы регуляции жидкого состояния крови и ее свертывания. М.: Медицина, 1975. 488 с.

19. Кудряшов Б.А., Ляпина Л.А., Азиева Л.Д. Комплексное соединение гепарина с гистамином, его физико-химические и биологические свойства // Вопр. мед. химии. 1990. Т. 36, № 4. С. 55-57.

20. Ляпина Л.А., Мясоедов Н.Ф., Андреева Л.А. и др. Комплекс гепарина с пептидом Arg-Pro-Gly-Pro и его антикоагулянтно-фибринолитические и гипогликемические эффекты // Изв. РАН. Серия биологическая. 2012. № 1. С. 72-77.
5. Lukashin B.P., Sofronov G.A. (1996). Radioprotective effect of cystamine and heparin in experiments on mice with different resistance. Bulletin of Experimental Biology and Medicine, 121 (5), 544-546. In Russ.

6. Lever R., Page C.P. (2002). Novel drug opportunities for heparin. Nat. Rev. Drug Discov., 1 (2), 140-148.

7. Coombe D.R., Kett W.C. (2005). Heparan sulfateprotein interactions: therapeutic potential through structure-function insights. Cell. Mol. Life Sci., 62 (4), 410-424.

8. Khomutov A.E., Pursanov K.A. (2011). Biological and Clinical Foundations of Apitherapy. Nizhny Novgorod, 400 p. In Russ.

9. Pursanov K.A., Khomutov A.E., Butylin A.G. (2009). The influence of heparin on antinociceptive properties of oxytocin. Med. Almanac, 4 (9), 198-200.

10. Khomutov A.E., Deryugina A.V. (2019). Heparinology: Physiological, Biochemical and Biomedical Aspects: Tutorial. Nizhny Novgorod, 620 p. In Russ.

11. Yamamura H., Ohya S., Muraki K., Imaizumi Y. (2012). Involvement of inositol 1,4,5-trisphosphate formation in the voltage-dependent regulation of the $\mathrm{Ca}^{2+}$ concentration in porcine coronary arterial smooth muscle cells. J. Pharmacol. Exp. Ther., 342 (2), 486-496.

12. Kondashevskaya M.V. (2010). Modern views of the role of heparin in hemostasis and regulation of enzymatic and hormonal activities. Annals of the Russian Academy of Medical Sciences, 7, 35-43.

13. Kondashevskaya M.V. (2012). The role of heparin in immune processes, inflammation and reparation. Clin. and Experimental Morphology, 5, 64-70.

14. Németh K., Kurucz I. (2005). Suppression of $\mathrm{Ca}^{2+}$ influx by unfractionated heparin in non-excitable intact cells via multiple mechanisms. Biochem. Pharmacol., 69 (6), 929-940.

15. Feofanova M.A., Frantseva Yu.V., Zhuravlev E.V., Baranova N.V., Potekha E.V. (2014). Chemical equilibriums in the system $\mathrm{CO}^{2+}$ ion-heparin-proline. Annals of the Tver State University, 2, 13-18.

16. Feofanova M.A., Frantseva Yu.V., Lapshin S.V. (2012). Complexation in the heparin-metal ion system. Russian Journal of Coordination Chemistry, 38 (5), 387-392.

17. Arsyutov O.V., Arsyutov V.P. (2013). The role of histamine, serotonin, catecholamines, heparin, and xanthine oxidase in healing of peritoneum damaged during a surgery. Bulletin of the Chuvash University, 3, 363-368.

18. Kudryashov B.A. (1975). Biological Problems of Regulation of the Liquid State of Blood and Its Coagulation. Moscow, 488 p. In Russ.

19. Kudryashov B.A., Lyapina L.A., Azieva L.D. (1990). Complex compound of heparin with histamine, its physicochemical and biological properties. Problems of Medical Chemistry, 36 (4), 55-57. In Russ.

20. Lyapina L.A., Myasoedov N.F., Andreeva L.A. et al. (2012). A complex of heparin with the peptide argpro-gly-pro and its anticoagulative, fibrinolytic, and hypoglycemia effects. Biology Bulletin, 1, 72-77.

21. Lyapina L.A., Obergan T.Yu., Grigorieva M.E., Maistrenko E.S., Kalugina M.D. (2015). Comparative study of anticoagulant heparin compounds with amino ac- 
21. Ляпина Л.А., Оберган Т.Ю., Григорьева М.Е., Майстренко Е.С., Калугина М.Д. Сравнительные исследования антикоагулянтных соединений гепарина с аминокислотами - аланином, валином и глицином // Междунар. журн. прикладных и фундамент. исследований. 2015. № 11. С. 412-415.

22. Иванова Д.М., Левицкая Н.Г., Андреева Л.А., Каменский А.А., Мясоедов Н.Ф. Сравнительное исследование анальгетической активности фрагмента $\mathrm{AKT \Gamma}_{4-10}$ и его аналога семакса // Бюл. эксперимент. биологии и медицины. 2007. Т. 143, № 1. С. 4-12.

23. Хомутов А.Е., Пурсанов К.А., Перепелюк З.В. Модификация гепарином кардиотропных эффектов тиролиберина на модели изолированного сердца крысы после тотальной ишемии // VIII Междунар. науч.-практ. конф. Прага, 2012. С. 11-18.

24. Hasbi A., Allouche S., Sichel F. et al. Internalization and recycling of the delta-opioid receptor are dependent on a phosphorylation-dephosphorylation mechanism // J. Pharmacol. Exp. Ther. 2000. Vol. 293 (1). P. 237-247.

25. Ляпина Л.А., Пасторова В.Е., Ульянова А.М., Тарасов Ю.А. Участие гепариновых комплексов в регуляции гемостатической и инсулярной систем организма // XVIII съезд физиологического общества им. И.П. Павлова: тез. докл. Казань, 2001. C. $379-380$.

26. Сергеев П.В., Шимановский Н.Л., Петров В.И. Рецепторы физиологически активных веществ. М.; Волгоград: Семь ветров, 1999. 640 с.

27. Дрозд Н.Н., Луньков А.П., Ильина А.В., Варламов В.П. Нейтрализация антикоагулянтной активности гепаринов конъюгатом кватернизированного хитозана с галловой кислотой // Изв. Уфимского научного центра РАН. 2018. № 3 (2). С. 7-12.

28. Судаков С.К., Башкатова В.Г., Колпаков А.А., Тригуб М.М. Периферическое введение лоперамида и метилналоксона подавляет тревожность у крыс // Бюл. эксперимент. биологии и медицины. 2010. T. 149, № 3. C. 244-246.

29. Перфилов Д.В., Баранов М.В., Черногоров Р.В. Способы оценки ноцицептивной чувствительности в экспериментальных исследованиях и клинике // Успехи физиологических наук. 2007. Т. 38, № 2. C. $75^{-80}$.

30. Гланц С. Медико-биологическая статистика. М.: Практика, 1999. 459 с.

31. Липатов В.А., Крюков А.А., Северинов Д.А., Саакян А.Р. Этические и правовые аспекты проведения экспериментальных биомедицинских исследований in vivo. Часть I // Рос. мед.-биол. вестн. им. академика И.П. Павлова. 2019. Т. 27, № 1. С. 80-92.

32. Липатов В.А., Крюков А.А., Северинов Д.А., Саакян А.Р. Этические и правовые аспекты проведения экспериментальных биомедицинских исследований in vivo. Часть II // Рос. мед.-биол. вестн. им. академика И.П. Павлова. 2019. Т. 27, № 2. С. 245-257.

33. Филаретова Л.П. Стресс в физиологических исследованиях // Рос. физиол. журн. им. И.М. Сеченова. 2010. T. 96, № 9. С. 924-935.

34. Кондашевская М.В., Кактурский Л.В. Нарушение адаптации при посттравматическом стрессовом расстройстве и его коррекция введением малых доз гепарина в эксперименте // Клин. и эксперимент. морфология. 2018. № 3. С. 63-68. ids - alanine, valine and glycine. Intern. Journal of Applied and Fundamental Research, 11, 412-415. In Russ.

22. Ivanova D.M., Levitskaya N.G., Andreeva L.A., Kamenskii A.A., Myasoedov N.F. (2007). Comparative study of analgesic activity of $\mathrm{ACTH}_{4-10}$ fragment and its analog semax. Bulletin of Experimental Biology and Medicine, 143 (1), 4-12. In Russ.

23. Khomutov A.E., Pursanov K.A., Perepeluyk Z.V. (2012). Modification of cardiotropic effects of thyroliberin with heparin in a model of an isolated rat heart after total ischemia. VIII International Scientific and Practical Conference, Praha, pp. 11-18. In Russ.

24. Hasbi A., Allouche S., Sichel F. et al. (2000). Internalization and recycling of the delta-opioid receptor are dependent on a phosphorylation-dephosphorylation mechanism. J. Pharmacol. Exp. Ther., 293 (1), 237247.

25. Lyapina L.A., Pastorova V.E., Ulyanova A.M., Tarasov Yu.A. (2001). Participation of heparin complexes in the regulation of hemostatic and insular systems of the body. XVIII Congress of the Pavlov Russian Physiological Society, Kazan, pp. 379-380. In Russ.

26. Sergeev P.V., Shimanovskiy N.L., Petrov V.I. (1999). Receptors of physiologically active substances. Moscow, 640 p. In Russ.

27. Drozd N.N., Lun'kov A.P., Il'ina A.V., Varlamov V.P. (2018). Neutralization of the anticoagulant activity of heparin by conjugates quaternized chitosan with gallic acid. Proceedings of the RAS Ufa Scientific Center, 3 (2), 7-12.

28. Sudakov S.K., Bashkatova V.G., Kolpakov A.A., Trigub M.M. (2010). Peripheral administration of loperamide and methylnaloxone decreases the degree of anxiety in rats. Bulletin of Experimental Biology and Medicine, 149 (3), 244-246. In Russ.

29. Perfilov D.V., Baranov M.V., Chernogorov R.V. (2007). Methods for assessing nociceptive sensitivity in experimental studies and clinical practice. Progress in Physiological Sciences, 38(2), 75-80. In Russ.

30. Glants S. (1999). Biomedical Statistics. Moscow, 459 p. In Russ.

31. Lipatov V.A., Kryukov A.A., Severinov D.A., Saakyan A.R. (2019). Ethical and legal aspects of in vivo experimental biomedical research. Part I. I.P. Pavlov Russian Medical and Biological Herald, 27 (1), 8092.

32. Lipatov V.A., Kryukov A.A., Severinov D.A., Saakyan A.R. (2019). Ethical and legal aspects of in vivo experimental biomedical research. Part II. Pavlov Russian Medical and Biological Herald, 27(2), 245257.

33. Filaretova L.P. (2010). Stress in physiological studies. Russian Journal of Physiology, 96 (9), 924-935.

34. Kondashevskaya M.V., Kaktursky L.V. (2018). Adaptation abnormalities in posttraumatic stress disorder corrected by low dose heparin injections in an experiment. Clin. And Experimental Morphology, 3, $63-68$.

35. Smith A., Surviladze Z., Gaudet E.A. et al. (2001). p110 $\beta$ and p110 $\delta$ phosphatidylinositol 3-kinases up-regulate FceRI-activated $\mathrm{Ca}^{2+}$ influx by enhancing inositol 1,4,5,-trisphosphate production. J. Biol. Chem., 276 (20), 17213-17220. 
35. Smith A., Surviladze Z., Gaudet E.A. et al. p110 $\beta$ and p110 $\delta$ phosphatidylinositol 3-kinases up-regulate FceRI-activated $\mathrm{Ca}^{2+}$ influx by enhancing inositol 1,4,5,-trisphosphate production // J. Biol. Chem. 2001. Vol. 276 (20). P. 17213-17220.

36. Хомутов А.Е., Пурсанов К.А., Лушникова О.В., Перепелюк 3.В. Потенцирование гепарином антиноцицептивного действия нейропептида FMRFa на супраспинальном уровне // Биомедицина. 2015. № 2. C. $73-79$.

\section{СВЕДЕНИЯ ОБ АВТОРАХ}

Хомутов Александр Евгеньевич - д-р биол. наук, профессор кафедры физиологии и анатомии Института биологии и биомедицины ФГАОУ ВО «Нижегородский государственный университет им. Н.И. Лобачевского».

Дерюгина Анна Вячеславовна - д-р биол. наук, доцент, заведующий кафедрой физиологии и анатомии Института биологии и биомедицины ФГАОУ $\mathrm{BO}$ «Нижегородский государственный университет им. Н.И. Лобачевского».

Лизунова Алла Сергеевна - канд. биол. наук, доцент кафедры фармакогнозии ФГБОУ ВО «Рязанский государственный медицинский университет им. академика И.П. Павлова» Минздрава России.

Боброва Зоя Владимировна - младший научный сотрудник лаборатории иммунохимии ФГБУН Институт физиологически активных веществ РАН (г. Черноголовка).

Образец цитирования: Хомутов А.Е., Дерюгина А.В., Лизунова А.С., Боброва З.В. Сенсибилизация гепарином мю-рецепторов, инициированных фентанилом // Journal of Siberian Medical Sciences. 2021. № 1. C. $20-32$.
36. Khomutov A.E., Pursanov K.A., Lushnikova O.V., Perepeluyk Z.V. (2015). Heparin potentiation of the antinociceptive action of the neuropeptide FMRFa at the supraspinal level. Biomedicine, 2, 73-79. In Russ.

\section{ABOUT THE AUTHORS}

${ }^{\dagger}$ Khomutov Aleksandr Evgenievich - Dr. Sci. (Biol.), Professor, Department of Physiology and Anatomy, Institute of Biology and Medicine, Lobachevsky State University of Nizhny Novgorod.

Deryugina Anna Vyacheslavovna - Dr. Sci. (Biol.), Associate Professor, Head, Department of Physiology and Anatomy, Institute of Biology and Medicine, Lobachevsky State University of Nizhny Novgorod.

Lizunova Alla Sergeevna - Cand. Sci. (Biol.), Associate Professor, Department of Pharmacognosy, Ryazan State Medical University n.a. academician I.P. Pavlov.

Bobrova Zoya Vladimirovna - Junior Researcher, Laboratory of Immunochemistry, Institute of Physiologically Active Substances (Chernogolovka).

Cit at ion example: Khomutov A.E., Deryugina A.V., Lizunova A.S., Bobrova Z.V. (2021). Heparin sensitization of fentanyl initiated mu-receptors. Journal of Siberian Medical Sciences, 1, 20-32. 